\title{
Design Analysis of Web-Based Furniture Marketing Information System
}

\author{
B. Ayshwarya, Phong Thanh Nguyen, Alismi, Satria Abadi, K. Shankar, Wahidah Hashim, \\ Aleksandr A. Korostelev, Andino Maseleno
}

\begin{abstract}
In the industrial world and with the progress of the times, technology will greatly help a small industry in managing beneficial information for consumers. Not all wood furniture industries have stores. However, the majority of shop owners in Pringsewu do not produce their own furniture. The owners who do not produce their own furniture receive merchandise from entrepreneurs who do not have shops. The owners provide furniture model orders needed by customers and users. In this case study, the data had been computerized so that consumers can receive information only by accessing the desired information. Furniture stores that build Web-Based Furniture Marketing Information Systems id to participate in providing data and information to people and can be accessed quickly, anywhere, and anytime.
\end{abstract}

Index Terms: Design analysis, web based, information system furniture.

\section{INTRODUCTION}

\section{A. Background}

The development of technology today [1-5]. The advancement of technology is greatly used by many people to access information quickly [6-10]. This information cannot be separated from the role of the web as a source of information on the internet [11-15]. In the sophisticated era, there are many companies provide information to people by using technology [16-21], one of them is furniture. It is done to be able to participate in providing data and information that can be trusted by consumers [22-25]. Furniture store is a medium-scale industry that is engaged in the field of furniture, especially from teak wood. In order to improve service to consumers, an information system design for marketing of teak wood furniture is made with the purpose of data flow and promotion can be accessed anywhere, anytime and by everyone.

Revised Manuscript Received on July 22, 2019.

B. Ayshwarya, Department of Computer Science, Kristu Jayanti College, Bangalore-560043, India.

Phong Thanh Nguyen, Department of Project Management, Ho Chi Minh City Open University (HCMCOU), Vietnam.

Alismi, Department of Information Systems, STMIK Pringsewu, Lampung, Indonesia.

Satria Abadi, Department of Information Systems, STMIK Pringsewu, Lampung, Indonesia.

K. Shankar, School of Computing, Kalasalingam Academy of Research and Education, Krishnankoil, India.

Wahidah Hashim, Institute of Informatics and Computing Energy, Universiti Tenaga Nasional, Malaysia.

Aleksandr A. Korostelev, Togliatti State University, Russia

Andino Maseleno, Institute of Informatics and Computing Energy, Universiti Tenaga Nasional, Malaysia. E-mail: andimaseleno@gmail.com.

\section{B. Objectives}

a. By web-based information system for furniture marketing, it can build a marketing information system.

b. By constructing a web-based furniture marketing information system, it is expected to increase sales and provide information to consumers about furniture products.

\section{THEORETICAL BASE}

\section{A. Definition of System}

System is a set of components that work together to achieve a goal [26-30]. Each component has a different function than others, but they still works together [31-35].

\section{B. Definition of Information}

Information is data that has been organized and has usability and benefits [36-39].

\section{Definition of Furniture}

Furniture is a term used for staircase that functions as a storage area for goods, seating, beds, working on something in the form of tables where items are placed on the surface.

\section{Definition of Web-Based Information System}

Web-based Furniture Information System is an information access service using Internet that connects users of information with servers as data sources. The data provided are information about furniture products.

\section{E. SDLC Method}

SDLC (Systems Development Life Cycle, or Systems Life Cycle is system engineering and software engineering, or the process of making and changing systems and the models and methods used to develop the systems [40-45]. This concept generally refers to computer systems or information SDLC is also a pattern taken to develop a software system that consists of : planning (planning), analysis (analysis), design (design), implementation (implementation), testing (testing) and management (maintenance) [46-49].

\section{System Development}

Life Cycle (SDLC) is the whole process of building a system through several steps.

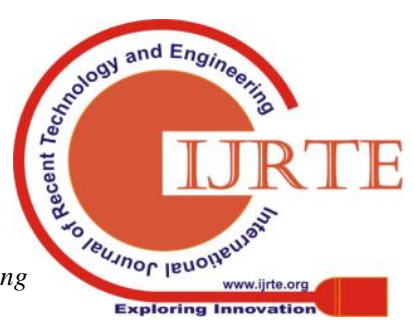


There are several SDLC models [50-54]. The model that is quite popular and widely used is waterfall [55-60]. Some other models of SDLC are fountain, spiral, rapid, prototyping, incremental, build \& fix, and synchronize \& stabilize [61-65].

\section{RESEARCH METHODOLOGY}

The method used by the author in developing and designing systems was a System Development Life Cycle (SDLC). In an SDLC cycle, there are six stages performed by researchers in developing and designing the system

1. Create running workflow analysis [66-70].

2. Specify the needs of the system, namely performing details about what is needed in developing the system and making plan relating to furniture information systems.

3. Creating design management workflows and programming design that are needed for the development of furniture information systems [71-75].

4. Develop information system by writting needed program.

5. Perform test of information system made.

6. Implement and maintain the system.

Reseachers applied the SDLC cycle writer sequentially, started from the first stage to the sixth stage. Every step that has finished then reviewed, sometimes with an expert user, especially in the requirements specification and system design stages to ensure that the stages have been done correctly and as expected. If not, the stage needs to be repeated or go back to the previous stage.

Review conducted by the author was quality control test. Quality control was carried out by the author to build the quality of the system. Author documented all stages in the cycle to facilitate maintenance and improvement of system functions.

This Marketing Information System Designed by creating a system flowchart that arranges how the marketing system from the furniture store before the computerized system and how the design of the development system, then it was followed by creating flow documents from the Data Flow Diagram.

\section{DESIGN ANALYSIS}

\section{A. Context Diagram}

This Marketing Information System Design by creating a system flowchart that configurates how the marketing system of the furniture store before the computerized system and how the design of the development system, followed by creating a Context Diagram document can be seen in the following Figure.

\section{B. ERD (Entity Relationship Diagram)}

The design of this marketing information system is by creating a system flowchart that arranges how the marketing system of the furniture store before the computerized system and how the design of the development system were followed by creating a flow document from the Entity Relationship Diagram (ERD).

\section{Website Implementation}

This output design will display the news about available goods in information system as shown in figure 1 .

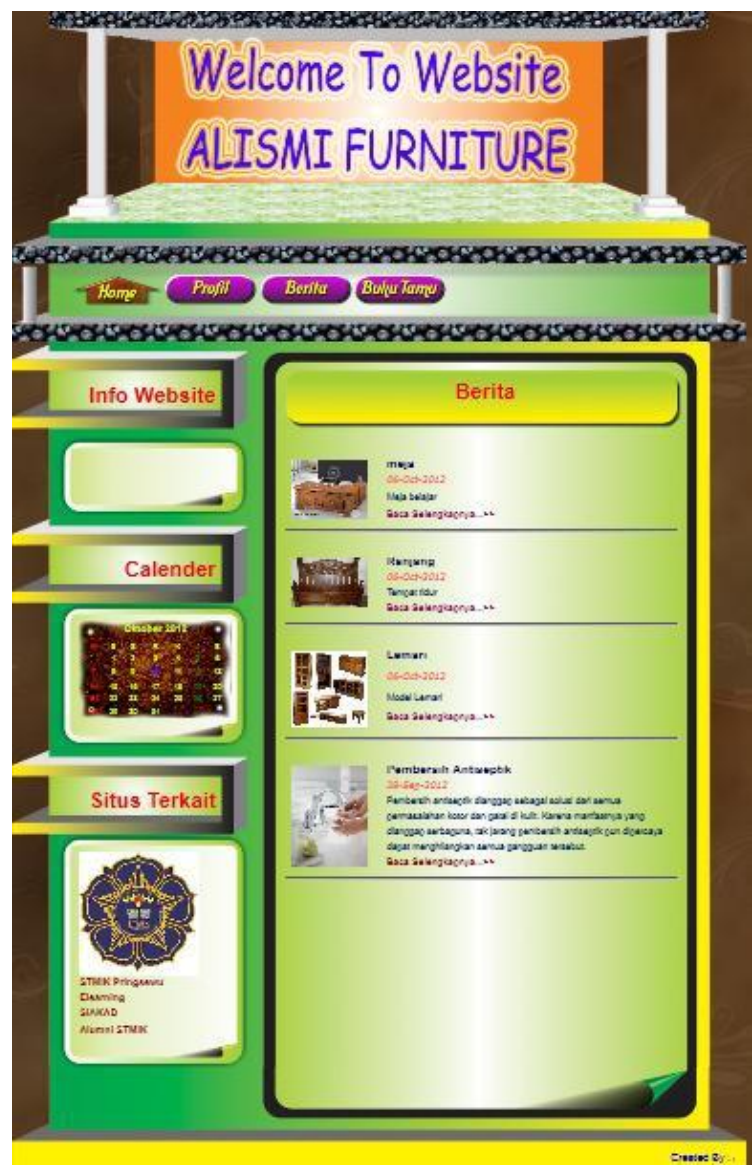

Figure 1. Display of Website Implementation

\section{CONCLUSION}

1. By this marketing information system, the furniture store can serve the consumer effectively because consumer can know the stock and type of thing effectively.

2. By this marketing information system, then the delivery of information has wider scope. It facilitates citizens to get information without having to come directly to the place

\section{REFERENCEES}

[1]. Elena V. Smirnova, B. Ayshwarya, Phong Thanh Nguyen, Wahidah Hashim, Andino Maseleno, Using Shell Programs in Educational and Methodological Support for Learning Foreign Language,

International Journal of Applied Exercise Physiology, Vol. 8 
(2.1), 2019. pp. 1027-1032.

[2]. Inga E. Rakhimbaeva, Aleksandr A. Korostelev, Indira A. Shakirova, B. Ayshwarya, Phong Thanh Nguyen, Wahidah Hashim, Andino Maseleno, Integration of the Educational and Didactic Systems in the Training of Future Teachers, International Journal of Applied Exercise Physiology, Vol. 8 (2.1), 2019. pp. 1033-1038.

[3]. Alla L. Busygina, Elena M. Chertakova, Darya B. Shtrikova, B. Ayshwarya, Phong Thanh Nguyen, Wahidah Hashim, Andino Maseleno, Professional forms of Employment in the Russian Federation: Problems and Challenges, International Journal of Applied Exercise Physiology, Vol. 8 (2.1), 2019. pp. 1039-1045.

[4]. Olga I. Pugach, Andrei V. Ochepovsky, Wahidah Hashim, Andino Maseleno, B.Ayshwarya, Phong Thanh Nguyen, To the use of English Words When Learning Programming, Information Systems and Technologies, International Journal of Applied Exercise Physiology, Vol. 8 (2.1), 2019. pp.

[5]. R. Fenny Syafariani, Andri Sahata Sitanggang, Andino Maseleno, Application of Backend and Frontend Systems on Go-Baby Application in Bandung City, International Journal of Recent Technology and Engineering (IJRTE), Vol. 7, Issue 6S5, pp. 125-131, 2019.

[6]. Natalia L. Ivanova, Nikolay Ivanovich Sinyavsky, Alexey Valerievich Fursov, Oksana Petrovna Denisova, Andino Maseleno, Future Oil and Gas Participation in the Implementation of Russian Physical Educational Complex «Ready for Labor and Defense» (Rld) Normatives, International Journal of Recent Technology and Engineering (IJRTE), Vol. 7, Issue 6S5, pp. 186-189, 2019.

[7]. Natalia P. Nikonova, Larisa N. Gorina, Andino Maseleno, Cooperation between the European Union and the Eurasian Union, International Journal of Recent Technology and Engineering (IJRTE), Vol. 7, Issue 6S5, pp. 201-203, 2019.

[8]. Natalie P. Nikonova, Larisa N. Gorina, Andino Maseleno, Inter-Regional Relationship Based on Geo Economics Requirements, International Journal of Recent Technology and Engineering (IJRTE), Vol. 7, Issue 6S5, pp. 204-206, 2019.

[9]. Fenny Syafariani R., Andri Sahata Sitanggang, Eko Yudhi Pramono, Wahidah Hashim, Andino Maseleno, Systems and Services Pattern Descriptions at Daycare, International Journal of 7, Issue 6S5, pp. 207-212, 2019.

[10]. Tri Susilowati, P. Manickam, G. Devika, K. Shankar, Latifah, Muhamad Muslihudin, Wahidah Hashim, Miftachul Huda, Aleksandr Aleeksevich Korostelev, Andino Maseleno, Decision Support 1046-1051. Students' Attitude to Healthy Lifestyle and Their Recent Technology and Engineering (IJRTE), Vol.

System for Determining Lecturer Scholarships for Doctoral Study Using CBR (Case-Based Reasoning) Method, International Journal of Recent Technology and Engineering (IJRTE), 2019. pp. 3281-3290.

[11]. Muhamad Muslihudin, M. Ilayaraja, K. Sathesh Kumar, K. Shankar, Jauharotun Jamilah, Dita Novitasari, Miftachul Huda, Wahidah Hashim, Irina V. Rudenko, Andino Maseleno, Decision Support System in Kindergarten Selection using TOPSIS Method, International Journal of Recent Technology and Engineering (IJRTE), 2019. pp.3291-3298.

[12]. Muhamad Muslihudin, G. Devika, P. Manickam, K. Shankar, Dian Permana Putra, Eki Pramudia Sukarno Putra, Miftachul Huda, Wahidah Hashim, Oksana P. Denisova, Andino Maseleno, Expert System in Determining Baby Disease using Web Mobile-based Weighted Product Method, International Journal of Recent Technology and Engineering (IJRTE), 2019. pp.3299-3308.

[13]. Muhamad Muslihudin, K. Sathesh Kumar, M. Ilayaraja, K. Shankar, Lailaturrohmah, Dian Permana Putra, Wahidah Hashim, Andino Maseleno, Expert System in Determining the Quality of Nutmeg Breed using Website-Based Forward Chaining Methods, International Journal of Recent Technology and Engineering (IJRTE), 2019. pp.3309-3318.

[14]. Muhamad Muslihudin, S. Hemalatha, K. Shankar, Eswaran Perumal, Nofiyanti, Satria Abadi, Wahidah Hashim, Andino Maseleno, Application of Expert System for Determining Export Quality Pepper Seeds using Website-Based Forward Chaining Method, International Journal of Recent Technology and Engineering (IJRTE), 2019. pp. 3319-3329.

[15].Muhamad Muslihudin, Rizky Purnama, Wahidah Hashim, Andino Maseleno, Selection of Temporary Landfill using Fuzzy Multiple Attribute, International Journal of Innovative Technology and Exploring Engineering, 2019. pp.598-604.

[16]. Muhamad Muslihudin, Siti Mukodimah, Erma Dwiyani, Trisnawati, Wahidah Hashim, Andino Maseleno, Fuzzy Logic Prediction of Dengue Hemorrhagic Fever Distribution in Pringsewu Region, International Journal of Innovative Technology and Exploring Engineering, 2019. pp.605-612.

[17].S. Senthil, B. Ayshwarya, Prediction of Lung Cancer using Blue Whale Optimizer Algorithm with Neural Network Classifier, Journal of Advanced Research in Dynamical and Control Systems, Volume 11, 02-Special Issue, 2019. pp. 1737-1748.

[18].Narges Bahrami, Sifeng Liu, Vadim Vitalievich $\begin{array}{lr}\text { Ponkratov, } & \text { Phong } \\ \text { Thanh } & \text { Nguyen, } \\ \text { Andino } & \text { Maseleno, }\end{array}$ 
Stephen Berti, Novel Load Management for Renewable Generation Sources/Battery System through Cut Energy Expenditure and Generate Revenue, International Journal of Ambient Energy, Taylor and Francis Online, 2019.

[19]. Aravindhan Surendar, J. Muralidharan, Ali Dehghan Saee, Andino Maseleno, Aleksandr Alekseevich Rudenko, David Ros, Mathematical modelling of free convection in an ellipse-rectangular annulus filled with nanofluid using LBM, Thermal Science and Engineering Progress, Elsevier, 2019

[20]. Bochkareva, T. N., Drozdov, V. A., Akhmetshin, E. M., Prikhodko, A. N., Gorbenko, A. V., \& Zakieva, R. R. (2018). Improving Information and Technical Support of HR Management System in the Educational Establishment. Paper presented at the Proceedings of the 31st International Business Information Management Association Conference Innovation Management and Education Excellence through Vision 2020, 3582-3589.

[21].Akhmetshin, E., Ilyina, I., Kulibanova, V., \& Teor, T. (2019). Special aspects of master data-based integrated management of region reputation in modern IT environment. Paper presented at the IOP Conference Series: Materials Science and Engineering, 497(1) doi:10.1088/1757-899X/497/1/012022

[22]. Atova, A. Z., Sitdikov, F. F., \& Klychova, G. S. (2018). Reporting in the area of sustainable development with information technology application. Management Science Letters, 8(7), 785-794. doi:10.5267/j.msl.2018.5.008

[23].Sychugov, A. A., Akhmetshin, E. M., Grishin, V. M., Shpakova, R. N., \& Plotnikov, A. V. (2019). Algorithm determine trust value to the distributed information systems elements. Journal of Mechanical Engineering Research and Developments, 42(2), 6-9. doi:10.26480/jmerd.02.2019.06.09.

[24]. Satria Abadi, Akmal Hawi, Akla, Ihsan Dacholfany, Miftachul Huda, Kamarul Shukri Mat Teh, Jaki Walidi, Wahidah Hashim, Andino Maseleno, Identification of Sundep, Leahopper and Fungus of Paddy by using Fuzzy SAW Method, International Journal of Pharmaceutical Research, Volume 11, Issue 1, January - March 2019.

[25].Andino Maseleno, Miftachul Huda, Kamarul Azmi Jasmi,Bushrah Basiron, Ismail Mustari, Abdul Ghaffar Don, Roslee bin Ahmad, Hau-Kashyap Approach for Student's Level of Expertise, Egyptian Informatics Journal, Elsevier, Vol. 20, Issue 1, March 2019, pp. 27-32.

[26].Liang Zhou, Hesam Kamyab, Aravindhan Surendar, Andino Maseleno, Aygul Z. Ibatova, Shreeshivadasan Chelliapan, Nima Karachi, Zohreh Parsaee, Novel Z-scheme composite $\mathrm{Ag} 2 \mathrm{CrO} 4 / \mathrm{NG} /$ polyimides as high performance nano catalyst for photoreduction of CO2: Design, fabrication, characterization and mechanism, Journal of Photochemistry and Photobiology A: Chemistry, Elsevier, Volume 368, 1 January 2019, pp 30-40.

[27]. Muhamad Rusliyadi, Azaharaini bin Hj. Mohd. Jamil, Marini Othman, Andino Maseleno, Ratna Tri Kumalasari, Agricultural Extension Policy, Agricultural Growth and Poverty Reduction in Indonesia, International Journal of Engineering and Technology (UAE), Vol. 7, No. 4, 2018, pp. 5539-5550.

[28]. Gunawan Budiyanto, Sri Ipnuwati, Sayyid Azam Al Gifari, Miftachul Huda, Burhanuddin Jalal, Aliza Abdul Latif, Andino Maseleno, April Lia Hananto, Web based expert system for diagnosing disease pest on banana plant, International Journal of Engineering and Technology(UAE), Vol. 7, No. 4, 2018, pp. 4715-4721.

[29].Elisabet Yunaeti Anggraeni, Pardimin, Ihsan Dacholfany, Akla, Miftachul Huda, Kamarul Shukri Mat Teh, Aminudin Hehsan, Juhazren Junaidi, Farahwahida Mohd Yusof, Hafiza Abas, Mohd Fauzi Abu Husin, Dina Apriani, Aliza Abdul Latif, Andino Maseleno, Modelling effectivenes of IS learning methodology with AHP method, International Journal of Engineering and Technology(UAE), Vol. 7, No. 4, 2018, pp. 4708-4714.

[30].Aditya Mulawarman, Ajat Sudrajat, Nedi Hendri, Karnawi Kamar, Dedi Mulyadi, Gunawan Budiyanto, Miftachul Huda, Aliza Abdul Latif, Andino Maseleno, FMADM for determining superior commodity at agroindustry area, International Journal of Engineering and Technology(UAE), Vol. 7, No. 4, 2018, pp. 4667-4673.

[31].Aprianti Putri Sujana, Andri Sahata Sitanggang, Andino Maseleno, Application of E-Transport through Android-Based Ticketing Applications, Journal of Advanced Research in Dynamical and Control Systems, Issue 13-Special Issue, 2018, pp. 1347-1356.

[32].Pardimin, Apriadi, Widhiya Ninsiana, M. Ihsan Dacholfany, Karnawi Kamar, Kamarul Shukri Mat Teh, Miftachul Huda, April Lia Hananto, Muhammad Muslihudin, K. Shankar, Natalia V. Kamenez, Andino Maseleno, Developing Multimedia Application Model for Basic Mathematics Learning, Journal of Advanced Research in Dynamical and Control Systems, Issue 14-Special Issue, 2018, pp. 1347-1356.

[33]. Natalia V. Kamenez, Olga Igorevna Vaganova, Zhanna Venediktovna Smirnova, Marina Nikolaevan Bulayeva, Ekaterina Andreevna Kuznetsova, Andino Maseleno, Experience 
of the use of electronic training in the educational process of the Russian higher educational institution, International Journal of Engineering and Technology(UAE), Vol. 7, No. 4, pp. 4085-4089, 2018.

[34].Olga Igorevna Vaganova, Ludmila N. Zanfir, Zhanna Venediktovna Smirnova, Elena Aleksandrovna Chelnokova, Svetlana Nikolaevna Kaznacheeva, Andino Maseleno, On the linguistic training of future teachers of unlike specialties under the conditions of Russian professional education, International Journal of Engineering and Technology(UAE), Vol. 7, No. 4, pp. 4090-4095, 2018.

[35].Olga Igorevna Vaganova, Natalia V. Kamenez, Vinnikova Irinia Sergeevna, Ekaterina Vladimirovna Vovk, Zhanna Venediktovna Smirnova, Andino Maseleno, Possibilities of information technologies to increase quality of educational services in Russia, International Journal of Engineering and Technology(UAE), Vol. 7, No. 4, pp. 4096-4102, 2018.

[36].Zhanna Venediktovna Smirnova, Ludmila N. Zanfir, Olga Igorevna Vaganova, Natalia Vasilevna Bystrova, Nina Vladimirovna Frolova, Andino Maseleno, WorldSkills as means of improving quality of pedagogical staff training, International Journal of Engineering and Technology(UAE), Vol. 7, No. 4, pp. 4103-4108, 2018.

[37]. Abdul Hamid, Ajat Sudrajat, Razaleigh Muhamat Kawangit, Abdul Ghafar Don, Miftachul Huda, Burhanuddin Jalal, Wahyu Akbar, Azura Onn, Andino Maseleno, Determining basic food quality and Technology(UAE), Vol. 7, No. 4, pp. 3548-3555, 2018.

[38]. Noca Yolanda Sari, Miftachul Huda, Kamarul Shukri Mat Teh, Anggia Sari, Ramona Ramli, Andino Maseleno, Decision support system for determining chili plant using fuzzy multiple attribute decision making, International Journal of Engineering and Technology(UAE), Vol. 7, No. 4, pp. 3556-3562, 2018.

[39]. Oktafianto, Ajat Sudrajat Kawangit, Razaleigh Muhamat Kawangit, Abdul Ghafar Don, Miftachul Huda, Amel Dhea Saputri,Aliza Abdul Latif, Andino Maseleno, Determining housing location using weighted product, International Journal of Engineering and Technology(UAE), Vol. 7, No. 4, pp. 3563-3568, 2018.

[40]. Satria Abadi, Miftachul Huda, Kamarul Shukri Mat Teh, Zulkiflee Haron, Mohd. Nasir Ripin, Aminudin Hehsan, Shamsul Sarip, Muhamad Rafiqi Hehsan, Musfika Amrullah, Andino Maseleno, Hazard Level of Vehicle Smoke by Fuzzy Multiple Attribute Decision Making with Simple Additive Weighting Method, International Journal of using SAW, International Journal of Engineering

Pharmaceutical Research, Vol. 10, Issue 4, 2018.

[41].Fauzi, Miftachul Huda, Kamarul Shukri Mat Teh, Zulkiflee Haron, Mohd. Nasir Ripin, Aminudin Hehsan, Hafiza Abas, Muhamad Rafiq, July Irawan, Satria Abadi, Andino Maseleno, The Design of Fuzzy Expert System Implementation for Analyzing Transmissible Disease of Human, International Journal of Pharmaceutical Research, Vol. 10, Issue 4, 2018.

[42]. Mohamed Elhoseny, K. Shankar, S.K. Lakshmanaprabu, Andino Maseleno, N. Arunkumar, Hybrid Optimization with Cryptography Encryption for Medical Image Security in Internet of Things, Neural Computing and Applications, Springer, October 2018, pp. 1-15.

[43].E. Laxmi Lydia, P. Krishna Kumar, K. Shankar, S.K. Lakshmanaprabu, R.M. Vidhyavathi, Andino Maseleno, Charismatic Document Clustering through Novel K-Means Non-negative Matrix Factorization (KNMF) Algorithm using Key Phrase Extraction, International Journal of Parallel Programming, Springer, 2018, pp. 1-19.

[44].K. Shankar, S.K. Lakshmanaprabu, Deepak Gupta, Andino Maseleno, Victor Hugo C. De Albuquerque, Optimal feature-basedmulti-kernel SVM approach for thyroid disease classification, The Journal of Supercomputing, Springer, Vol. 74, no. 259, 2018, pp. 1-16.

[45].M. Miftakul Amin, Adi Sutrisman, Deris Stiawan, Andino Maseleno, Design Restful WebService of National Population Database for supporting E-health interoperability service, Journal of Theoretical and Applied Information Technology, vol. 96, issue 15, 2018.

[46].A.H. Motlagh, S.V. Klyuev, Aravindhan Surendar, Aygul Z. Ibatova, Andino Maseleno, Catalytic Gasification of Oil Sludge with Calcined Dolomite, Petroleum Science and Technology, Taylor and Francis, pp. 1-5, 2018.

[47]. Aravindhan Surendar, Alireza Bozorgian, Andino Maseleno, Lubov K. Ilyashenko, Meysam Najafi, Oxidation of Toxic Gases via Ge-B36N36 and Ge-C72 Nanocages as Potential Calaysts, Inorganic Chemistry Communications, Elsevier, Vol. 96, October 2018, pp. 206-210.

[48]. Abdolhamid Namdarian, Amin Goljanian Tabrizi, Andino Maseleno, Abdolkhaled Mohammadi, Seyyed Ebrahim Mossavifard, One step synthesis of rGO-Ni3S2 nano-cubes composite for high-performance supercapacitor electrodes, International Journal of Hydrogen Energy, Elsevier, vol. 43, Issue 37, 13 September 2018, pp.17780-17787.

[49]. Aravindhan Surendar, Lina G. Akhmetov, Lubov K. Ilyashenko, $\begin{array}{r}\text { Andino } \\ \text { Maseleno, }\end{array}$ Vahid
Samavatian, Effect of 

and thermal conductivity of a porous lead-free solder joint, IEEE Transactions on Components, Packaging, and Manufacturing Technology, 2018, pp. 1769-1776.

[50]. Aravindhan Surendar, Vahid Samavatian, Andino Maseleno, Aygul Z. Ibatova, Majid Samavatian, Effect of solder layer thickness of thermo-mechanical reliability of a power electronic system, Journal of Material Science: Materials in Electronics, Springer, September 2018, Volume 29, Issue 17, pp. 15249-15258.

[51]. Majid Samavatian, Lubov K. Ilyashenko, Aravindhan Surendar, Andino Maseleno, Vahid Samavatian, Effect of System Design on Fatigue Life of Solder Joints in BGA Packages Under Vibration at Random Frequencies, Journal of Electronic Materials, November 2018, Volume 47, Issue 11, pp. 6781-6790.

[52].Ilgar Javanshir, Andino Maseleno, Shahin Tasoujian, Majid Oveisi, Optimization of suspension system of heavy off-road vehicle for stability enhancement using integrated anti-roll bar and coiling spring mechanism, Journal of Central South University, September 2018, Volume 25, Issue 9, pp 2289-2298.

[53]. Andino Maseleno, Alicia Y.C. Tang, Moamin A. Mahmoud, Marini Othman, K. Shankar, Big Data and E-Learning in Education, International Journal of Computer Science and Network Security, 2018, Vol. 18, No. 5, pp. 171- 174.

[54]. Muhammad Assahubulkahfi, Yahaya Md. Sam, Andino Maseleno, Miftachul Huda, LQR Tuning by Particle Swarm Optimization of Full Car Suspension System, International Journal of Engineering and Technology(UAE), Vol. 7, No. 2.13, 2018, pp. 328-331.

[55].Dwi Kurniasih Kamarul Azmi Jasmi, Bushrah Basiron, Miftachul Huda, Andino Maseleno, The uses of fuzzy logic method for finding agriculture and livestock value of potential village, International Journal of Engineering and Technology(UAE), Vol. 7, No. 3, 2018, pp. 1091-1095.

[56].Hana Adela, Kamarul Azmi Jasmi, Bushrah Basiron, Miftachul Huda, Andino Maseleno, Selection of Dancer Member using Simple Additive Weighting, International Journal of Engineering and Technology(UAE), Vol. 7, No. 3, 2018, pp. 1096-1107.

[57]. Tri Susilowati, M. Ihsan Dacholfany, Sudirman Aminin, Afiful Ikhwan, Badlihisham Mohd. Nasir, Miftachul Huda, Adi Prasetyo, Andino Maseleno, Fiqih Satria, Sri Hartati, Wulandari, Getting Parents Involved in Child's School: Using Attendance Application System based on SMS Gateway, International Journal of Engineering and Technology(UAE), Vol. 7, No. 2.27, 2018, pp. thermal cycle loadings on mechanical properties

167-174.

[58]. Andino Maseleno, Alicia Y.C. Tang, Moamin A. Mahmoud, Marini Othman, Suhendi Saputra, Muhamad Muslihudin, Fuzzy AHP Method to Determine Headache Types based on Symptoms, Investigacion Clinica, Vol. 58, No. 1, 2017.

[59].Andino Maseleno, Miftachul Huda, Maragustam Siregar, Roslee Ahmad, Aminudin Hehsan, Zulkiflee Haroon, Mohd Nasir Ripin, Siti Suhaila Ikhwani, Kamarul Azmi Jasmi, Combining the Previous Measure of Evidence to Educational Entrance Examination, Journal of Artificial Intelligence, Vol. 10, No. 3, pp. 85-90, 2017. ISSN: 2077-2173. doi: 3923/jai.2017.85.90

[60]. Miftachul Huda, Andino Maseleno, Kamarul Azmi Jasmi, Ismail Mustari, Bushrah Basiron, Strengthening Interaction from Direct to Virtual Basis: Insights from Ethical and Professional Empowerment, International Journal of Applied Engineering Research, Vol. 12, No. 17, pp. 6901-6909, 2017. ISSN: 0973-4562.

[61].Miftachul Huda, Andino Maseleno, Masitah Shahrill, Kamarul Azmi Jasmi, Ismail Mustari, Bushrah Basiron, Exploring Adaptive Teaching Competencies in Big Data Era, International Journal of Emerging Technologies in Learning, Vol. 12, No. 3, pp. 68-83, 2017. ISSN: 1863-0383. doi: 10.3991/ijet.v12i03.6434.

[62]. Andino Maseleno, Glenn Hardaker, Noraisikin Sabani, Nabilah Suhaili, Data on multicultural education and diagnostic information profiling: Culture, learning styles and creativity, Data in Brief, Elsevier, Vol. 9, pp. 1048-1051, December 2016. doi: 10.1016/j.dib.2016.11.024.

[63]. Andino Maseleno, Md. Mahmud Hasan, Norjaidi Tuah, Charles Rangga Tabbu, Fuzzy Logic and Dempster-Shafer Theory to Predict The Risk of Highly Pathogenic Avian Influenza H5N1 Spreading, World Applied Science Journal, Vol. 34, No. 8, pp. 995-1003, 2016. ISSN: 1818-4952. doi: 10.5829/idosi.wasj.2016.34.8.15688

[64].Andino Maseleno, Glenn Hardaker, Malaria Detection using Mathematical Theory of Evidence, Songklanakarin Journal of Science and Technology, Vol. 38, No. 3, pp. 257-263, 2016. ISSN: 0125-3395. doi:10.14456/sjst-psu.2016.35

[65]. Andino Maseleno, Md. Mahmud Hasan, Muhammad Muslihudin, Tri Susilowati, Finding Kicking Range of Sepak Takraw Game: Fuzzy Logic and Dempster-Shafer Theory Approach, Indonesian Journal of Electrical Engineering and Computer Science, Vol. 2, No. 1, pp. 187 - 193, 2016. ISSN: 2502-4752. doi: 10.11591/ijeecs.v2.i1.pp187-193

[66]. Andino Maseleno, Md. Mahmud Hasan, Norjaidi Tuah, Fauzi, Muhammad 
Muslihudin, Fuzzy Logic Combined with Dempster-Shafer Theory for African Trypanosomiasis Spreading Prediction, Middle-East Journal of Scientific Research, Vol. 23, No. 9, pp. 2307 - 2317, 2015. ISSN: 1990-9233, doi: 10.5829/idosi.mejsr.2015.23.09.22600

[67]. Andino Maseleno, Md. Mahmud Hasan, Norjaidi Tuah, Combining Fuzzy Logic and Dempster-Shafer Theory, TELKOMNIKA, Vol. 16, No. 3, pp. 583-590, 2015. ISSN: 2302-404. doi: 10.11591/telkomnika.v16i3.9370

[68].Bibi Rawiyah Mulung, Andino Maseleno, Proposed SMART Traffic Control Signal in Brunei Darussalam, TELKOMNIKA, Vol. 15, No. 2, pp. 277-282, 2015. ISSN: 2302-4046. doi: 10.11591/telkomnika.v15i2.8109

[69].P. Uma Maheswari, P. Manickam, K. Sathesh Kumar, Andino Maseleno, K. Shankar, Bat optimization algorithm with fuzzy based PIT sharing (BF-PIT) algorithm for Named Data Networking (NDN), Journal of Intelligent \& Fuzzy Systems, IOS Press, pp. 1-8, 2019.

[70]. Grigory Olegovich Yarygin, Aleksandr Aleeksevich Korostelev, Rafis H. Mukhutdinov, Andino Maseleno, Elections and Russian Citizens Residing Overseas: Prospects for Internet Voting, International Journal of Recent Technology and Engineering (IJRTE), Vol. 7, Issue 6S5, pp. 52-57, 2019.

[71].Larisa Akhunzhanovna Apanasyuk, Elena Vladimirovna Smirnova, Rafis H. Mukhutdinov, Andino Maseleno, The Problem of the Organization of Socio-Cultural Environment for Adaptation and Development of a Student-Migrant's Bilingual Identity in the Conditions of the Russian Higher Education, International Journal of Recent Technology and Engineering (IJRTE), Vol. 7, Issue 6S5, pp. 63-70, 2019.

[72]. Alla L. Busygina, Liliya A. Meteleva, Darya B. Shtrikova, Rafis H. Mukhutdinov, Andino Maseleno, Bases of Formation of Women's Professional Mentality in Russia, International Journal of Recent Technology and Engineering (IJRTE), Vol. 7, Issue 6S5, pp. 71-77, 2019.

[73].Oleg N. Yarygin, Aleksandr A. Korostelev, Linar G. Akhmetov, Andino Maseleno, Modeling of Competence as a Tool of Goal Setting for Education in Modern Society, International Journal of Recent Technology and Engineering (IJRTE), Vol. 7, Issue 6S5, pp. 78-86, 2019.

[74]. Raven John, Aleksandr A. Korostelev, Oleg N. Yarygin, Rafis H. Mukhutdinov, Andino Maseleno, The Genesys and Base Concepts of Competentology, International Journal of Recent Technology and Engineering (IJRTE), Vol. 7, Issue 6S5, pp. 87-95, 2019.

[75].Bogdanova Anna Vladimirovna, Aleksandr
Alekseevich Korostelev, Rafis H. Mukhutdinov, Indira A. Shakirova, Andino Maseleno, Formulation of the Problem of Mathematical Modeling of Accommodation of Basic Stations of Cellular Communication in Residential Territories for Students of It-Directions of Preparation, International Journal of Recent Technology and Engineering (IJRTE), Vol. 7, Issue 6S5, pp. 96-100, 2019. 